\title{
THE URGENCE REGULATION OF BUSINESS ACTIVITIES ON ISLAMIC MICROFINANCE INSTITUTION ACCORDING LAW NO. 1 YEAR 2013 OF MICROFINANCE INSTITUTIONS
}

\author{
Prawitra Thalib, Sri Hajati, Faizal Kurniawan dan Komari Aldiansyah \\ Faculty of Law, Universitas Airlangga \\ Jl. Dharmawangsa Dalam Selatan - Surabaya \\ Email: prawitra@fh.unair.ac.id; sri.hajati.unair@gmail.com; faizal@fh.unair.ac.id
}

\begin{abstract}
Abstrack
Microfinance Institutions (hereinafter referred to as MFIs) are financial institutions that function as intermediary institutions that aim not only to seek profit, but have another goal, namely social goals whose activities are more community development. MFIs in conducting business activities can be carried out conventionally or based on Sharia Principles. The business activities carried out by MFIs include trading activities, namely in the service sector. In carrying out Shariah MFI business activities, it must be based on Sharia Principles. The method used in writing this article is normative research with a statutory and conceptual approach. The results of the study show that the Sharia Principles in this context are guided by the basic principles of Muamalah. The important objective in this research is the regulation in the laws and regulations regarding this matter whether it is in accordance with sharia principles. Harmonization between legislation as positive law in Indonesia with sharia principles sourced from the Qur'an and Hadith as the main legal sources of Islamic law is absolutely necessary to ensure legal certainty.
\end{abstract}

Key words: Microfinance Institution, sharia principles, micro, small and medium enterprises.

\begin{abstract}
Abstrak
Lembaga Keuangan Mikro (selanjutnya disebut LKM) merupakan lembaga keuangan yang berfungsi sebagai lembaga intermediary yang bertujuan tidak hanya semata-mata mencari keuntungan (profit motive) saja, tetapi mempunyai tujuan lain yakni tujuan sosial (social motive) yang kegiatannya lebih bersifat community development. LKM dalam melakukan kegiatan usaha bisa dilakukan secara konvensional atau berbasis pada Prinsip Syariah. Kegiatan usaha yang dilakukan LKM termasuk dalam kegiatan perdagangan yakni dalam bidang jasa. Dalam menjalankan kegiatan usahanya LKM Syariah harus berdasarkan Prinsip Syariah. Metode yang digunakan dalam penulisan artikel ini adalah penelitian normatif dengan pendekatan peraturan perundang-undangan dan pendekatan konseptual. Hasil penelitian menunjukkan Prinsip Syariah dalam konteks ini berpedoman pada Prinsip dasar Muamalah. Tujuan dalam penelitian ini yang penting yaitu pengaturan dalam peraturan perundang-undangan terkait hal ini apakah sudah sesuai dengan prinsip syariah. Harmonisasi antara peraturan perundang-undangan sebagai hukum positif di Indonesia dengan prinsip-prinsip syariah yang bersumber pada Al-quran dan Hadist sebagai sumber hokum utama hokum islam mutlak diperlukan adanya untuk menjamin kepastian hukum.
\end{abstract}

Kata kunci: Lembaga Keuangan Mikro, prinsip syariah, usaha mikro kecil dan menengah. 


\section{Introduction}

According to Law No. 20 of 2008 on micro, small and medium enterprises (hereinafter called MSMES), small businesses are defined as productive economic activities. This business is carried out by individuals or business entities that are not subsidiaries or non-subsidiaries owned, mastered or part either directly or indirectly from medium enterprises or large enterprises and meet other criteria. Reported from Bappenas website, in Indonesia, MSME has a contribution or big role, including: expansion of employment opportunity and absorption of manpower. Gross domestic product (GDP) formation. The provision of safety nets is especially for low income communities to conduct productive economic activities. Based on data from the Ministry of Cooperatives and SMES, the economic census of the Central Statistics agency in 2016 showed the magnitude of SMES contribution. MSMES absorbs up to 89.2 percent of the total workforce, providing up to 99 percent of total employment, accounting for 60.34 percent of total national GDP, accounting for 14.17 percent of total exports, accounting for 58.18 percent of the total investment. ${ }^{1}$ Micro Small business has also proved to have the ability to survive in the face of a high crisis. When the economic crisis was in nature by ASEAN countries no exception in Indonesia in 1997-1998, the property business sector experienced a deep downturn, while the micro enterprise sector could still be able to stand. Micro enterprises are also able to keep Indonesia not increasingly slumped. $^{2}$

The main problem faced by the MSMES sector is the issue of capital, sometimes in gaining a modal from their bank having difficulties. One of the reason is the high credit interest rate and the needs of collateral minded in obtaining credit that they are difficult to fulfill. The provision of credit facilities as the main activity of the banking institutions essentially has the same features since long ago. However, in its current development it leads to variations and patterns that combine technological developments with the accompanying market segments and regulations. If viewed and in terms of pattern and creditor classification, then one of the banking products in giving credit to the community is through credit micro, small, and medium enterprises. ${ }^{3}$

In an effort to encourage community empowerment, especially middle-to-lower income communities and micro, small, and medium enterprises (MSMES) are required comprehensive support from financial

1 Arum Sutrisni, "Peran UMKM dalam Perekonomian Indonesia", https://www.kompas.com/skola/ $\mathrm{read} / 2019 / 12 / 20 / 120000469 /$ peran-umkm-dalam-perekonomian-indonesia?page=all\#: :text=Dilansir\%20 dari\%20situs\%20Bappenas\%2C\%20di,untuk\%20menjalankan\%20kegiatan\%20ekonomi\%20produktif., accessed 20 June 2020.

2 Asuransi MAG, "Peran dan Jenis Lembaga Keuangan Mikro di Indonesia, http://www.mag.co.id/lembagakeuanganmikro/\#: :text=Jenis\%2DJenis\%20LKM\%20di\%20Indonesia\&text=Contoh\%20dari\%20yang\%20 formal\%20ini,BPR.\%20Selanjutnya\%20adalah\%20semi\%20formal., accessed 19 June 2020.

3 Sri Adiningsih, "Revitalisasi UMKM”, http://www.niriah.com, accessed 19 June 2020. 
institutions. During this time, MSMES have constrained funding access to formal financial institutions. To overcome these obstacles, in the community has grown and developed many non-bank financial institutions that do business development services activities and community empowerment, either government or community established. ${ }^{4}$ These institutions are known as microfinance institutions (herein after called MFIS). But the MFIS are many who have not been legally licensed and have a business license. In order to provide a strong legal basis for the operationalization of MFIS, on 8 January 2013 has been enacted in Law No. 1 of 2013 on microfinance institutions.

Law No. 1 year 2013 on microfinance institutions defines MFIS as a financial institution specifically established to provide business development services and community empowerment, either through lending or financing in micro-scale efforts to members and communities, the management of deposits, and the provision of business consulting services that are not solely seeking profit. The definition implies that the MFI is an institution of profit motive which is also social motive, whose activities are more community-development without waiving its role as financial intermediation institution. As a financial institution that serves as an intermediation institution, MFIS also conduct a lending activity, whose activities in addition to providing loans but also demanded to provide awareness of saving to the public, especially low-income communities. Microfinance itself is a financial sector activity in the form of gathering funds and lending or financing on a micro-scale with a simple procedure to poor and/or low-income people. ${ }^{5}$

Internationally the term self-financing micro or microfinance refers to financial services that are given to small entrepreneurs or small businesses, who usually do not have banking access to the high cost of transactions imposed by banking institutions. Microfinance is a financing that can cover many types of financial services, including of or of, which is the type of loan that is given to customers who have scale to medium enterprises and tend to have never been related to the banking world. Authority Financial Services Regulation (hereinafter called POJK) number 62/POJK.05/2015 concerning amendment to regulation of the Financial Services Authority No. 13/POJK. 05/2014 concerning the implementation of micro finance institutions govern the business activities of MFIS. First, MFIS business activities include business development services and community empowerment, either through loan or financing in micro-scale business to members and community, management of deposits, and the provision of business development consulting services. Both business activities

4 Prawitra Thalib, et., al., "The Function of Deposit Insurances Institution to Create a Solid Banking System for the Sake of Continuity of Infrastructure Development in Indonesia", International Journal of Innovation, Creativity and Change, Volume 5, Issue 2, (Special Edition 2019): 394.

5 I Gede Kajeng Baskara, “Lembaga Keuangan Mikro di Indonesia.” Jurnal Buletin Studi Ekonomi, Vol. 18 , No. 2, (2013): 115 . 
that can be done conventionally or based on Shariah principles. Third, MFIS can conduct fee-based activities as long as they do not conflict with the provisions of legislation in the financial services sector. ${ }^{6}$ Provisions on MFIS-based business activities appear after the update by POJK number 62/POJK. $05 / 2015$. In the explanation mentioned that includes fee-based business activities that are: marketing financial services products, among others, micro insurance; In cooperation with the financing company through a channeling or joint financing; and become an agent of financial services Institution of financial service provider without office in the Financial Framework inclusive (clever practice).

The concept of trading is not limited to only the goods sectoder, but also cover the services sector. Even in the concept of free trade the products that are sold are not only limited to goods or services, but also include the manpower and the flow of capital that they have. So with the free trade, the company of a country can establish its branches in other countries. The workforce of a country can also find work in other countries with little or no barriers. A simple illustration of free trade is a market that can be entered wider and crosses the territorial boundaries of a country. ${ }^{7}$ In the concept of international trade is the same, that international trade is the activity of the trade of goods and services, conducted by a resident of a country with the residents of other countries. Foreign trade arises because there is not a single country in the world that can produce all goods and services to meet the needs of all its inhabitants. ${ }^{8}$ Article 1 Figure 7 of Law No. 7 of 2014 on trade defining trade as trade is the order of activities related to the transaction of goods and/or services within the country and beyond the borders of the country for the purpose of transferring rights to goods and/or services for obtaining rewards or compensation. Considering the trade meaning is widespread enough in the field of goods and services, the type of business activities conducted by the MFIS is part of the trade, more specifically in the field of services.

MFIS in conducting their business activities are conventionally or based on sharia principles. The form of legal entity of MFIS can be cooperative or in the form of limited liability company. For MFIS form the company's legal entity, at least 60 percent of the shares owned by the District government/city or village-owned enterprises, the remainder of the share ownership of Corporation can be owned by Indonesian citizen or cooperatives with the ownership of Indonesian citizen at most 20 percent. Based on data from the Authotrity Finanacial Services (hereinafter called OJK) report Quarter III Year 2019

6 OJK, "Informasi Umum Lembaga Keuangan Mikro", https://www.ojk.go.id/id/kanal/iknb/Pages/LembagaKeuangan-Micro.aspx, accessed 18 June 2020.

7 SimulasiKredit, "Inilah Keuntungan dan Kerugian dari Perdagangan Bebas”, https:/www.simulasikredit.com/ inilah-keuntungan-dan-kerugian-dari-perdagangan-bebas/, accessed 18 June 2020.

8 Anonymous, "Makalah Konsep Perdagangan Internasional", http://kumpulanmakalah94.blogspot. com/2015/08/makalah-konsep-perdagangan-internasional.html, accessed 19 June 2020. 
MKM engaged in the conventional sector amounted to 129 MKM with details 100 in the form of cooperative and 29 in the form of limited liability company. Meanwhile, the sharia sector amounted to 75 MFIS, with details of 74 cooperatives and 1 in the form of limited liability company. From this data can be nearly one hundred percent MFIS engaged in the sharia sector of the legal entity in the form of cooperative. Islamic MFIS Cooperative form can also be called Baitul Maal Wa Tamwil (hereinafter called BMT).

Supervision of the principles of sharia principles on sharia financial institutions is very urgent and main to be implemented where it is the core or initi of the operation of sharia financial institutions. Supervision is also necessary to find the practice of fraud or cheating practices conducted by an Islamic financial institution for the sole benefit and to protect the customers or the parties who transact or conduct transactions with sharia financial institutions. The forms of cooperation contracts for the results in sharia financial institutions can generally be done in four akad (Islamic contract), namely musyarakah, mudharabah, muzara'ah and musaqah. However, in its application, the principle used in the profit sharing system, generally using cooperation contracts on the mutanaqisah and mudharabah contract.

Sharia financial institution (Islamic MFIS) is not only responsible for the quantity of calculation of profit figures because in addition to the profit unisex belief that he will be responsible to Allah in running the MFIS. Islamic MFIS must be consistent to carry out responsibility for the implementation of Sharia principles. Islamic MFIS lives in the midst of the community by carrying the Sharia platform.

\section{Characteristic Islamic Micro Financial} Institution

Islamic MFIS conducting business activities based on Shariah principles shall be obliged to use the contract in accordance with the Sharia principles. So Sharia trading is a trade that complies with sharia principles. Sharia principle is the principle of Islamic law in the intermediation activities based on the fatwa issued by the Indonesian Ulama Council, in this case is the National Sharia board (hereinafter called DSN MUI), for which the fatwa hereinafter outlined in the relevant regulations. ${ }^{9}$ Islamic Sharia principles differ from conventional financial institutions. Sharia financial institutions include MFIS as financial institutions with Shariah principles initially present as a choice as well as a solution for Muslims who want to avoid the practice of banks or conventional financial institutions that use Ribawi system but finally also can be an option for other than Muslims. The implementation of LKS means it is compulsory to be Shariah liable to keep not only the practice in the Islamic MFIS is free of usury but also must be free from elements

$9 \quad$ Ibid. h. 59. 
of maysir/gambling and Ghoror/speculation and must not harm each parties. ${ }^{10}$ Islam ordered to avoid this because it is considered as doing zhalim or damage the organizer of the Islamic MFIS is required to have not only business vision an sich aiming to dredge the high-height profit with the exclusion of sharia but also must have sharia vision. The process for Islamic MFIS to be in the principle of sharia principle when operating into a joint responsibility include the manager of LKS and state institutions that are appointed to perform the processes and procedures to keep the LKS in the corridor that should and does not do the the the reason to be in the guise of sharia-based camouflage in its practice and operations. ${ }^{11}$

The characteristic of Shari'ah is perfect (Ta'amul), harmonious (Wasathiyah), and dynamic (Harakah). Muhammad Ali Al-Sayis said that the most prominent characteristics of sharia are three things, namely 1 . Not troublesome and always avoid the tribulation in its execution, 2. Maintain human benefit and, 3. Always implement justice in its application. The above characters are in accordance with the principles contained in Quran Chapter Al-A'raf verse 157, ie not hard, little burden, gradually, there is looseness and in accordance with the general benefits. Business in Islam is in the study of Fiqh Muamalah. While the Fiqh rulings terminology defined as the law relating to the act of Human Law on the issues of the worldliness. ${ }^{12}$ For example, in the issue of buying and selling, debt-receivables, trade cooperation, Union, cooperation in the cultivation of land and tenancy. ${ }^{13}$

It can therefore be asserted that this rulings is governed with the good that man can fulfill his needs without giving Mudhorot to others. In general, the basic principle is the fundamental foundation that makes the basic guidelines for every Muslim who believes in the behavior of the code. This guideline is based on the Qur'an and Hadith as a framework for the build up of Islamic economics that has the ethics value and norm value. This is because in the view of Islam, economic activity is always associated with the principle of life that is sourced in the Qur'an and hadith every Muslim individual.

The basic principles of Sharia Finance (Maliyah), among others,: ${ }^{14}$

1. Principles of Tauhid/faith/Unity. Tawhid or faith in Allah Al Mighty is the original principle/dominant principle of the Islamic economy. Tauhid are fundamental or basic in Islam, and the Islamic value system is based on this

10 Prawitra Thalib, "Distinction of Characteristics Sharia and Fiqh on Islamic Law", Yuridika, Volume 33 No. 3 , (September 2018): 441.

11 Ibid. h. 54.

12 Prawitra Thalib, Syariah Pengakuan dan Perlindungan Hak dan Kewajban Manusia dalam Perspektif Hukum Islam, (Surabaya: Airlangga University Press, 2018) hlm. 49.

13 Nasrun Haroen, Fiqh Muamalah, (Jakarta: Gaya Media Pratama, 2007, hlm. 12.

14 Syed Nawab Haider Naqvi, Islam, Economics, and Society, alih bahasa M. Saiful Anam dan M. Ufuqul Mubin, (Yogyakarta: Pustaka Pelajar, 2009), hlm. 39-54 . 
belief. Tauhid made human beings a divine being, a god-based creature. That is, every building and activity of human life must be based on tauhidi values. Furthermore, this principle delivers economic behavior in the economic activities to believe that human property owned belongs to Allah Al Mighty. The results of production that can make money or wealth is a result of human engineering sourced from the raw material of God. ${ }^{15}$ That is, in fact all economic sources are the property of Allah Al Mighty, in this principle it is understood that anything in this nature is God's.

2. Forbid usury.

Usury or riba formulated by the science of jurisprudence as a special addition that belongs to one party of two parties involved without any particular remuneration. Sayheed Sabiq defines usury or riba as an addition to the capital, whether the addition is few or many. Related to Riba's haraam, it is undeniable that all forms of usury or riba are forbidden absolute in the Qur'an. Some verses in the Qur'an firmly banned usury. Although some of them were lowered in Mecca only indicate displehaving against Riba. In Indonesia, riba's safety is determined by the MUI in January 2004. Based on the Fatwa MUI No. 1 year 2004, it is stated that usury is an addition (Ziyadah) without any reward that occurs because of the determination in the payment that was promised earlier, and this is called riba nasi'ah. It was decided also in the fatwa that the money-flowering practice of today has fulfilled the criteria of usury that occurred in the era of Rasulullah Peace be Upon Him, namely riba nasi'ah. Thus, the practice of this money-usury is one of the forms of riba. Asserted also in this fatwa that: (a) for the existing office/ network of sharia financial institutions and easy to reach, is not allowed to make transactions based on interest calculation; (b) For areas that have no office/network of financial institutions Sharia, it is permissible to conduct transactions at conventional financial institutions based on the principle of Dharurat/Hajat. ${ }^{16}$

3. Prohibition of Gharar and Maysir. ${ }^{17}$ Monologically, Gharar is interpreted by the Fiqh scholars as ignorance of the result of a matter (transaction), or obscurity between good and bad. ${ }^{18}$ Meanwhile, Muhammad Ayub expressed that according to the terminology Fuqaha (Islamic legal scholar), Gharar

15 Tonic Tangkau, et., al., "Analysis on Non Muslim Heir Position Towards the Inheritance of Muslim Testator in Indonesia”, Yuridika, Volume 35, No. 2, (May 2020): 392.

16 M. Cholil Nafis, " Kajian dan analisis terhadap bunga bank dalam perspektif Teori", hlm. 140-153.

17 Trisadini Prasastinah Usanti and Prawitra Thalib, "Sharia Principles on Information Technology-Based Financing Services", Yuridika, Volume 35, No. 1, (January 2020): 158.

18 Abdullah Al-Mushlih dan Shalah Ash-Shawi, Fikih, hlm. 379. 
is the sale of an item that is not in place or sale of an item of "Aqibah" (consequence) unknown or sales which includes uncertainty in which a person does not know whether the agreement is carried out or not, such as the sale of fish in the sea or birds in the air. ${ }^{19}$ The Qur'an uses the word maisyir for a risk game, derived from the word usr (ease and pleasure), meaning that gambling seeks to collect treasures without work, and the term Maisyir is generally applied in all gambling activities. In the context of Indonesia, the Law No. 21 of 2008 on Sharia banking defines maiysir as a transaction suspended to an uncertain or profitable state. $^{20}$

4. Recommended trading by sharing profits and risks.

Islam strongly encourages its people to be actively involved in trading. The study of the Qur'an and Sunnah of the Prophet Muhammad Peace be Upon Him, that Islam is more likely to support business and trade activities. Most of these trading orders mainly describe the trade as a Fadhl of God, the gift and grace of God. The trading topic in the Qur'an is revealed with the word Tijarah authorizes which means to spread the capital for profit. The word Tijarah authorizes is expressed by the Qur'an by 9 times. Another word used Qur'an to show trades is bai'un called as many as 6 times. The Qur'an assesses trade is a worthy profession among various legal sources of income. Islam also gives considerable emphasis on trade as a way to gain wealth. This is confirmed by the Qur'an in Quran Chapter Al-Baqarah (2): 275, which in this verse trades is termed al Bai.

5. Don't acknowledge the concept of time value of money.

Experts in the Islamic economy recognise the benefits of money as a media exchange. Prophet Muhammad Peace be Upon Him himself like the use of money compared to exchanging goods with goods. Al-Ghazali expressed that in Islam the purpose of the creation of money is as a means of exchange and the standard value of goods, then money can not be treated as other commodity goods. In more detail, Al-Ghazali explained some functions that have the following money: a). Qiwam Ad-Dunya, meaning that money is a tool that can be used to assess the goods as well as compare it to other items. Money actually has no value of its own but can show a comparison of the value of an item with another. The money according to Al-Ghazali as Judge Mutawasit, that is money can be made a clear standard in determining the value of different goods. b). At-Tabadul tools, i.e. money as a means of exchanging goods 
in a transaction or often referred to as medium of change. With the knew the comparison of values or prices between the goods to be exchanged then the goods can be represented by money in the raid. c). Means of achievement of objectives and to obtain other goods. Actually this function is the description of money function as a means of exchanging.

6. Financing based on real assets.

The main pillar of Islamic economics is creating a system that supports the investment climate in the presence of zakat as a disincentive tool for the accumulation of property, prohibition of usury to encourage investment optimization, and prohibition of maisyir or gambling and speculation to drive productivity on every investment. Therefore, Ascarya concluded that the Islamic economy is a real economic pattern that does not recognize the presence of parallel dichotomy in the real sector and monetary or financial sectors. The financial sector is the driving and supporting the smooth productive activity in the real sector. ${ }^{21}$ Then attributed to the financing in Sharia finance, the Islamic economy underlined that financing in Sharia banking is not selling money that relies on interest income on the principal of the loan invested, but from the share of profits gained by employers.

The usury (riba) are clearly and firmly banned in Islam. This interest is one of the distinguishing characteristics of sharia banking with conventional banking. And one of the wisdom of the prohibition of interest is expressed by Al-Ghazali because the usury/riba prevents people run real economic activity. The reason is that when someone who has money is allowed to make more money by based on interest, both on the transaction that is settled at that time or whose completion is postponed, it will be easy for him to produce without having to struggle in the activity of the real economy. This leads to barriers to the real interests of mankind, because the interests of humanity cannot be protected without any real trading, industrial, and construction skills. ${ }^{22}$

7. The chastity of Islamic Contract/akad. Akad derived from Arabic word aqod means bond, Alliance, Treaty and agreement (al-Ittifaq). While the term akad is confirmed as a legal relationship created by the binding of two statements, of which flows the legal consequences regarding the subject of his contract. ${ }^{23}$ Based on the understanding in relation to the agreement, it is an agreement between

21 Ascarya, Akad dan Produk Bank Syariah: Konsep dan Praktek di Beberapa Negar, (Jakarta: Bank Indonesia, 2006), hlm. 246.

22 Ayub, Op.cit., h. 92

23 Ayub, Op.cit., h. 104. 
two parties voluntarily, and an obligation to each reciprocal. Furthermore, in the transaction, the contract is divided into two categories, namely commercial contract and non-commercial contract. Commercial contract (Akad Tijarah) is an agreement/contract that aims to seek financial gain, such as in the field of buying and selling namely Akad Bai 'Maushufah, Bai ' Sharf, Bai ' Murabahah; In the field of trade namely Akad Syirkah and qiradh; In agriculture such as Akad Masaaqah and Muzaraah; And in the field of services such as Akad Ijaarah and Ji'aalah/Ju'aalah. As for non-commercial agreements (Akad Tabarru) is contract agreement that does not result in financial gain that aims to realize social goodness or lead to non-commercial benefits such as the principle of help, empathy and so on. Examples include the Akad Rahn (pledge), Akad qardl (loan), Akad Wadi'ah (deposit).

Further, Islam assesses that in economic activity, Akad occupies a very important position. With other expressions, Islam strongly emphasizes the urgency of contracts in economic relations. This is due to the agreement in the contract that restricts the relationship between the two parties involved in a contract, and will bind the relationship in the present and in the future. Also because of the contract that is the basis of the relationship that is the implementation of the orientation of the two people who do the Covenant, described in the agreement (contract) by both parties. Based on the explanation it can be asserted that Islam emphasizes the importance of contracts in economic relations. On the basis of that Islamic also enforce obligations in accordance with the Agreement (contract) and disclosure of information as a sacred duty. It is intended to reduce the risk of asymmetric and moral hazard information. ${ }^{24}$

The activities undertaken by sharia financial institutions are framed by akad based on the principle as mentioned in article 21 of the rule of Supreme Court number 2 year 2008 concerning the compilation of Sharia economic Law (KHES), it is mentioned that Akad is conducted based on principle, namely: first, endeavyati/voluntary; Every contract is done at the will of the parties. Avoid compulsion due to pressure of either party or other party. Second, trust/keep the promise; Every contract must be exercised by the parties in accordance with the agreement set forth by the same at the same time spared the injury. Third, the endeavor/prudence; Every contract is done in a timely and careful manner. Fourth, luzum/unchanged; Every contract is carried out with clear objectives and careful calculations that avoid the practice of speculation or maisir. Fifth, mutually beneficial, each contract is done to meet the interests of the parties so as to prevent the practice of manipulation and harm either 
party. Sixth, Taswiyah/equality, the parties in each akad have equal positions and have a balanced rights and obligations. ${ }^{25}$ Seventh, transparency; Each contract is carried out with balanced parties ' accountability. Eighth, ability; Each contract is done according to the ability of the parties, so it does not become an excessive burden to the person concerned. Ninth, Taisir/ease; Each contract is done by mutual convenience to each party to be able to implement it according to its ability. Tenth, good faith; Akad is done in order to enforce the benefits, do not contain any elements of traps and other bad deeds. Eleventh, for the lawful; Not contrary to law, not prohibited by law and not unlawful.

Please also note the laws and regulations in Indonesia on the terms of the agreement. Which is stipulated in article 1320 BW. There are 4 elements of the valid condition of an agreement of a cumulative nature, meaning all must be fulfilled. The two objective elements that if not fulfilled have the effect of null and void hokum for the sake of the hokum of such an agreement. That is an element of a particular object or subject and a permissible causa. Elements of Agreement and Proficiency are subjective elements. Which if not fulfilled in the case of the undone of such an agreement. If carefully analyzed the elements contained in $1320 \mathrm{BW}$ and Article 21 perma No. 2 of 2008 about KHES about the principles that exist in the agreement complement each other. Article 21 affirms the guarantee of shariah compliance.

\section{Intermediation characteristics}

on

\section{Islamic microfinance institutions.}

According to article 1 (1) of law No. 1 of 2013 on microfinance institutions, referred to as Islamic MFIS is a financial institution that is specially established to provide business development services and community empowerment, either through loans or financing in micro-scale business to members and society, the management of deposits, and the provision of business development consulting services that are not solely seeking profit. Based on the above definitions can be understood that Islamic MFIS is a financial institution that serves as a intermediary institution that aims not only to seek profit (profit motive) only, but has another objective that is social motive that activities are more community development.. Apart from conducting conventional activities, MFIS can also operate on sharia principles. Especially for Islamic microfinance institutions (Islamic MFIS), activities carried out in the form of financing or deposits. Financing herein is defined as providing funds to the community that must be returned in accordance with the principles of Sharia (see article 1 (4) Law MSMES). MSMES in conducting its business should refer to the fatwa issued by the National Sharia Board of the Indonesian

25 Prinsip keadilan tidak secara tersurat dalam asas-asas akad sebagaimana diatur pada Kompilasi Hukum Ekonomi Islam, akan tetapi makna keadilan tersirat dari asas kesetaraan/taswiyah. 
Ulema Council (DSN-MUI). ${ }^{26}$ In addition, MSMES is also obliged to form the Sharia supervisory board (DPS) in charge of giving advice and advice to directors or managers, and supervising the Islamic MFIS activities in accordance with Sharia principles.

The arrangement in Article 13 POJK NUMBER 62/POJK.05/2015 as the form of Islamic MFIS adherence to the sharia principle. In this article, the MFIS that conduct business activities based on sharia principles must use the agreement in accordance with the Sharia principles. Akad in accordance with Sharia principles includes: Business activities gathering deposits are carried out using the contract Wadiah, Mudharabah, or other Akad that does not contradict the sharia principles and approved by the OJK, The financing business activities carried out by the use of Akad Mudharabah, Musyarakah, Murabahah, Ijarah, Salam, Istishna, Ijarah the Muntahiah bit Tamlik, or other akad that is not contrary to the Shariah principles and approved by the OJK, Consulting and business development activities conducted by using Akad Ijarah, Ju'alah or other contract that does not contradict sharia principles and approved by the OJK, Financing activities through the acceptance of loans are conducted using the Akad Qordh, or other agreement that does not contradict sharia principles and approved by the OJK.

In order to obtain approval from the OJK as the competent authorities conducting the above business activities, Islamic MFIS apply for OJK by attaching the fatwa DSN MUI. Islamic MFIS conducting business activities based on sharia principles can also conduct social fund management and welfare of Zakat, Infaq, charity, and Waqf in accordance with the provisions of prevailing laws and regulations. That is to be noted in the management of social funds above must be done bookkeeping separately. The Islamic MFIS prior to operation must be obtained first from the OJK. MSMES in conducting its business in one area of village, subdistrict, or district/city. If MSMES conducts business activities exceeding 1 (one) district/city area, it is mandatory to change the form into a bank. In terms of the construction, arrangement, and supervision of Islamic MFIS, both legal entities and limited liability company, conducted by the OJK. In connection with the construction of the Islamic MFIS, a cooperative legal entity, OJK will coordinate with the Ministry that organizes cooperative affairs.

Before the enacted of law No. 1 of 2013 on microfinance institutions, MSMES in Indonesia is known as Baitul Mal wa Tamwil (BMT) or Islamic cooperatives to save loans and financing. The above agencies are generally cooperative legal entities. Based on law No. 25 of 1992 about the urban scale specifically regulated in the regulation of the Minister of Cooperatives and Small and medium enterprises of the Republic of Indonesia No. 16/Per/M. KUM/IX/2015 on 
the implementation of business activities save borrowing and financing cooperatives, the licensing, establishment, supervision and development of the body of the cooperative type of KSPPS must be Based on the explanation above, it is understood that BMT/ KSPSS is a microfinance institution that operates based on the principle of sharia that is legally cooperative under the management of the Ministry of Cooperatives and Small and medium enterprises. But after law No. 1 year 2013 then the legal entity form of BMT is Islamic MFIS. BMT has an important role in the national economy. BMT grows and develops rapidly, so its existence contributes to increasing the business of small and medium society. Several functions that are executed by BMT in addition to raising funds also function to distribute funds with the services of funds that are fed/channeled and have social functions as Baitul Maal. Until now there is no clear data on the number of BMT and its spread.

Regarding disputes arising based on sharia agreements, the dispute enters into the scope of sharia economic disputes or sharia banking. The decision of the Constitutional Court No. 93/PUU-X/2012 regarding the authority to resolve sharia banking disputes that revokes the provisions of Article 55 paragraph (2) of Law No. 21 of 2008 on Sharia Banking affirms that sharia banking disputes constitute the absolute insanity of the Religious Court. Regarding the resolution of non-litigation disputes recognized its existence and carried out in a manner that does not conflict with sharia principles that have been fated by the National Sharia Council namely: deliberation (can be by the form of negotiating or mediation) or through the Sharia Arbitration Board or BASYARNAS.

\section{Conclusion}

The MFIS function in encouraging the growth of Sharia business activities must be in accordance with sharia principles. Sharia principle in the business activities of BMT MFIS must be guided on the basic principle of muamala where there are at least eight principles namely the principle of Tauhid/ faith/Unity, Riba's prohibition, ban Gharar and Maysir; Recommended trading by sharing profits and risks, no introduction to the concept of time value of money, financing is based on real assets, and the chastity of Akad. Characteristics MFIS is implementing in the field of Sharia business activites. according article 13 POJK No. 62/POJK.05/2015 on the implementation of microfinance institutions. Hopefully in the implementation of what has been regulated in the legislation about MFIS, especially the MFI Sharia can be implemented with full trustt. 


\section{REFERENCES}

\section{Books}

Akmal Tarigan, Azhari. Tafsir Ayat-Ayat Ekonomi. Bandung: Citapustaka Media Perintis, 2012.

Ali al-Sayis, Muhammad. Tarikh al-Fiqh al-Islam. Mesir: Qoriah.

Al-Mushlih, Abdullah dan Shalah Ash-Shawi, Fikih.

Ascarya. Akad dan Produk Bank Syariah: Konsep dan Praktek di Beberapa Negara. Jakarta: Bank Indonesia, 2006.

Ayub, Muhammad. Understanding Islamic Finance. England: John Wiley \& Sons Ltd., 2007.

Cholil Nafis, M.. Kajian dan Analisis Terhadap Bunga Bank dalam Prespektif Teori”. Haider Naqvi, Nawab. Islam, Economics, and Society. alih bahasa M. Saiful Anam dan M. Ufuqul Mubin. Yogyakarta: Pustaka Pelajar 2009.

Haroen, Nasrun. Fiqh Muamalah. Jakarta: Gaya Media Pratama, 2007.

Ifham Sholihin, Ahmad. Buku Pintar Ekonomi

Syariah. Jakarta: Gramedia Pustaka Utama, 2010.

Sabiq, Sayyid. Fiqh al-Sunnah. Kairo:

Maktabah Dâr al-Turas, Juz III.

Thalib, Prawitra. Syariah Pengakuan dan Perlindungan Hak dan Kewajban Manusia dalam Perspektif Hukum Islam. Surabaya: Airlangga University Press, 2018.

\section{Journal}

Budiono, Arief. "Penerapan Prinsip Syariah Pada Lembaga Keuangan Syariah”. Jurnal Law and Justice Vol. 2, No. 1, (April 2017).

Gede Kajeng Baskara, I, “Lembaga Keuangan Mikro di Indonesia." Jurnal Buletin Studi Ekonomi, Vol. 18, No. 2, (2013).

Kosim, H. "Filsafat Perbankan Syari'ah" Al-Amwaal, Edisi 1, (2013).

Tangkau, Tonic et.,al.. "Analysis on Non Muslim Heir Position Towards the Inheritance of Muslim Testator in Indonesia”. Yuridika, Volume 35, No. 2, (May 2020): 392.

Thalib, Prawitra . "Distinction of Characteristics Sharia and Fiqh on Islamic Law". Yuridika, Volume 33 No.

3, (September 2018): 441.

Thalib, Prawitra et.,al.. "The Function of Deposit Insurances Institution to Create a Solid Banking System for the Sake of Continuity of Infrastructure Development in Indonesia”. International Journal of Innovation, Creativity and Change, Volume 5, Issue 2, (Special Edition 2019): 394.

Thalib, Prawitra et.,al.. "The Function of Sharia Supervisory Board in Financing Practices by Sharia Bank in Indonesia", Business and Management Studies: an International Journal, Volume 6, Issue 4 (2018): 1072. 
Usanti, Trisadini Prasastinah and Prawitra Thalib. "Sharia Principles on Information Technology-Based Financing Services". Yuridika, Volume 35, No. 1, (January 2020): 158.

\section{Internet}

Adiningsih, Sri. "Revitalisasi UMKM”. http:// www.niriah.com. Diakses 19 June 2020.

Anonymous. "Makalah Konsep Perdagangan Internasional". http:// kumpulanmakalah94.blogspot. com/2015/08/makalah-konsepperdagangan-internasional.html. Diakses 19 Juni 2020.

MAG, Asuransi. "Peran dan Jenis Lembaga Keuangan Mikro di Indonesia”. http://www.mag.co.id/lembagaganmikro/\#: :text=Jenis\%2DJenis $\% 20$ $\begin{array}{lllllllllll}\mathrm{L} & \mathrm{K} & \mathrm{M} & \% & 2 & 0 & \mathrm{~d} & \mathrm{i} & \% & 2 & 0\end{array}$ Indonesia\&text $=$ Contoh $\% 20$ dari $\% 20$ yang\%20 formal\%20ini,BPR.\%20 S e lanjutny a \% 20 a d a 1 a h \% 20 semi\%20formal. Diakses 19 Juni 2020.
OJK. "Informasi Umum Lembaga Keuangan Mikro". https://www.ojk.go.id/id/ kanal/iknb/Pages/Lembaga-KeuanganMicro.aspx. Diakses 18 Juni 2020.

Simulasi Kredit. "Inilah Keuntungan dan Kerugian dari Perdagangan Bebas". https://www.simulasikredit.com/ inilah-keuntungan-dan-kerugian-dariperdagangan-bebas/. Diakses 18 Juni 2020.

Rasyid, Abdul. "Sekilas Tentang Lembaga Keuangan Mikro Syariah”. https:// business-law.binus.ac.id/2017/03/31/ sekilas-tentang-lembaga-keuanganmikro-syariah-di-indonesia/. Diakses 20 Juni 2020.

Sutrisni, Arum. "Peran UMKM dalam Perekonomian Indonesia”. https://www.kompas.com/skola/ $\mathrm{read} / 2019 / 12 / 20 / 120000469 /$ peran-umkm-dalam-perekonomiandonesia?page $=$ all\#: : text $=$ Dilansir $\% 20$ dari $\% 20$ situs $\% 20$ Bappenas $\% 2 \mathrm{C} \% 20$ di, untuk\% 20 menjalankan \% 20 kegiatan\%20ekonomi\%20produktif.. Diakses pada tanggal 20 Juni 2020. 